\title{
A Review Based Study on Problem-Solving Ability of School Students in Relation to their Academic Achievement
}

Anuradha Ghatak" ${ }^{1}$, Prof. Kavita Mittal ${ }^{2}$

${ }^{* 1}$ Research Scholar, Faculty of Education, Banasthali Vidyapith, Rajasthan, India. ${ }^{2}$ Professor, Faculty of Education, Banasthali Vidyapith, Rajasthan, India

\section{ABSTRACT}

Studies were reviewed to find out the relationship between problem-solving ability and academic achievement of school students. It was found that for the last few years, there is a significant positive relation between Problem-Solving Ability and Academic Achievement of school students. The review of various studies revealed that the problem-solving ability of boys is significantly higher than the girls. The study also concluded that there is a positive correlation between various factors like (personality, study behavior, learning style, scientific attitude, intellectual ability, examination anxiety etc.) and academic achievement.

\section{Keywords : Problem-Solving Ability, School Students and Academic Achievement.}

\section{INTRODUCTION}

In our society academic achievement is considered as a key point to judge one's total capabilities. Hence academic achievement attributes a very incumbent place in education as well as learning process. "Academic Achievement is the knowledge attained or skill developed in the school subjects, usually designed by test scores or by marks assigned by teachers"(Carter 1958). Achievement is influence by personality, encouragement, knowledge, education and training. There are many other factors which also influence the academic achievement of students like problem-solving ability, intelligence, study habits, socio-economic status, personality etc. Problem-solving ability is one important factor influencing academic achievement of students.

Academic achievement generally refers to the levels of proficiency attained in some academic work. It encourages the students to work hard and learn more.
It is the status of students learning and refers to knowledge attained and skills develop during their academic work which is assessed by the teachers. The academic achievement of the same student differs from time to time from one class to another. Academic achievement is one of the most important aims of education. The success or failure of a student is measured in terms of academic achievement.

The term Academic Achievement is the combination of two words academic and achievement. In this the word 'Academic' is related to formal education. It is derived from the word 'Academy' means school, where special types of instructions are imparted. The term academic means institutional system of formal education in school, college and university.

Achievement is an accomplishment of success in bringing a desired end. Academic Achievement plays a very significant and pivotal role in the attainment of harmonious development of child. It refers to the 
knowledge attained and skill developed in the different subjects. Academic Achievement is multi dimensional phenomenon. It is a product of interaction between several factors and operations in the pupils such as abilities, motivation, interest and attitude and a complicated set of forces operating in functional set up of the school.

According to Jonassen (2010) "most important cognitive goal of education (formal and informal) in every educational context (public schools, universities and corporate training) is problem solving". Problem-Solving process is the careful analysis of details of a problem to reach a solution. Effective problem solving demands proper conceptual understanding.

Problem-Solving Ability may be said to be a deliberate and purposeful act on the part of an individual. It helps in the realization of the set goals or objectives by inverting some novel methods or systematically following some planned step for removal of the interferences and obstacles when usual methods like trial and error, habit formation and conditioning fail. Problem-Solving is the framework or pattern within which creative thinking and reasoning take place. It is the ability to think and reason in different complex situations. People who have learned effective problem-solving techniques are able to solve problems at higher level of complexity than more intelligent people who have not such training. Problem-Solving Ability is highly correlated with intelligence, reasoning ability and mathematical ability.

\section{OBJECTIVES}

- To review and analyze the published literature on the problem solving ability of school students.
- To analyze the academic achievement of school students.

- To study the relationship between problemsolving ability and academic achievement of school students.

- To identify the factors that correlates problemsolving ability of school students.

\section{METHODS AND MATERIALS}

The study included researches conducted in India and abroad, published in various journals.

\section{REVIEW OF LITERATURE}

Gakhar et al. (2003) studied creativity, problem solving and personality in relation to scholastic achievement with the objective to study the relationship between academic achievement and problem solving by taking a sample of 545 students of senior secondary school and found that problem solving ability was significant and positively correlated with mathematical achievement.

Salami, S. O. and Aremu, A. Oyesoni (2006) studied on relationship between problem-solving ability and study behavior among school going adolescents in southwestern Nigeria. A descriptive survey research design was employed in this study. The participants for this study were 430 final senior secondary school students selected by stratified random sampling technique. Researcher found that the problem solving ability correlated significantly with study behavior and it is significantly predictive of the secondary school students study behavior.

Sharma (2007) studied problem solving ability and scientific attitude as determinant of academic achievement of higher secondary students and found that high achievers had high problem solving ability 
in comparison to average and low achievers; there exist positive relationship between achievement, problem solving ability and scientific attitude.

Jose, Nisha M. and Thomas, Rainal P. (2011) studied on Problem-Solving Ability and Scholastic Achievement of Secondary School Students. The main objectives of the study were (i) to find out whether there is any significant difference in the problem solving ability of secondary school learners with respect to gender, locale and type of school and (ii) to find out whether there is any significant difference in relationship between problem solving ability and scholastic achievement of secondary school learners with respect to gender, locate and type of school. The sample was comprised of 320 secondary school students of Kottayam district. Survey Method was adopted in the study. The major findings were, boys have higher problem solving ability compared to girls. Problem Solving Ability of students in rural school is greater than the students in urban school; private school students have significantly higher problem solving ability when compared to government school students and both government and private school students possess greater problem solving ability but the school students possess greater problem solving ability but the scholastic achievement of government school students are low.

Manjula, M.and Natraj, P.N. (2012) focuses on problem solving ability among the matriculation school students of Cuddalore district. Normative survey method has been used to collect data. By using random sampling technique 644, IX standard matriculation school students have been chosen and involved in this study. In the present investigation descriptive analysis and differential analysis statistical techniques were used. The results revealed that (i) the problem solving ability of students are low in matriculation schools at Cuddalore district. (ii) investigation also reveals that there is no significant difference in respect of the sub samples, type of family, mothers' education, fathers' occupation and mothers' occupation, while in respect of gender, locality, fathers' education and parental monthly income there is significant difference on their problem solving ability.

James, A.O.and Adewale, O.A.(2012) studied on relationship between Senior Secondary Schools Students' Achievement in Mathematical-Problem Solving and Intellectual Abilities Tests. The study was aimed at establishing the relationship between the achievement of secondary school students in mathematical problem solving and their achievement in intellectual ability test using factor analysis. The study population consisted of all the students in Senior Secondary Schools (SSS) in Ondo State. Out of this population, a sample of 206 students was purposively selected from three senatorial districts of the State. Seven instruments (six on intellectual abilities and one on mathematical problem solving) were administered on the respondents. The finding of the study showed that a significant relationship existed between mathematical problem solving and intellectual abilities (verbal, induction and numerical abilities) of the students. Thus, teachers should provide avenue for students to improve their intellectual abilities of verbal, induction, numerical, retention and other abilities.

Anboucarassy .B. (2015) studied on Problem solving ability of higher secondary students in relation to their learning styles. The samples selected for the study were higher secondary school students from different schools in Pondicherry. The sample size 300 was drawn from various schools. The tool used to collect data is Problem solving ability test standardized by L.N. Dubey and Styles of learning 
and thinking tool standardized by D. Venkatraman. The study showed that problem solving ability of higher secondary students is average in nature. It was found that problem-solving ability had a positive relationship with learning.

Chauhan, Poonam and Shrma, Neha (2015) the main aim of this study was to analyze the problem solving ability among intellectually gifted students and investigated whether gender and location influenced problem solving ability of intellectually gifted students or not. The sample for the present study comprised of 30 intellectually gifted (16 female and 14 male) students from 10 different rural and urban senior secondary schools of Aligarh District. Raven's Advanced Progressive Matrices developed by Raven, J.C., Court, J.H. and Raven,J.(1977) and Problem Solving Ability Test developed by Dubey, L.N.tools employed for data collection. Correlation and Two way ANOVA techniques are used for data analysis. The result of this study revealed that there is low problem solving ability among intellectually gifted students. Intellectually gifted boys showed higher problem solving ability than girls and there is no significant difference between rural and urban intellectually gifted students with respect to their problem solving ability. Further, the finding showed the significant interaction effect of gender and location on problem solving ability of the intellectually gifted students.

Panju, N.and Kaur, Bhupinder (2015) studied and compared the problem solving ability among senior secondary school students. Problem Solving Ability Test (Dubey,2005) was used to collect data. The findings of the study revealed that school students possessed problem solving ability ranging from average to low. The results of the study also highlighted insignificant difference in problem solving ability among adolescent boys and girls. Mean, S.D. and t-test were used for statistical analysis.

Agnihotri,A.K.(2015) conducted a study on ProblemSolving Ability among Senior Secondary School Students of Govt. Senior Secondary Schools of Hamirpur district of Himachal Pradesh. Objectives of the study were to compare the senior secondary school boys and girls' students of science, commerce and arts with respect to their Problem-Solving Ability In the present study, Problem Solving Ability test constructed by L.N. Dubey has been used to collect data. There are 20 items in Problem solving ability test. It is found in the present study that the students of Science and Commerce streams have the higher level of problem solving ability as compare to the students of Arts stream. On the other hand there was no significant difference in the level of problemsolving ability on the gender basis.

Kumari, Jyoti (2016) studied on Problem-Solving Ability of Senior Secondary School Students. The main objectives of the study were- to study the difference in the level of problem-solving ability among senior secondary school students in relation to type of school, their stream and gender. A sample of 320 students of government and private schools was taken from Tehsil Nurpur and Indora of Kangra District of Himachal Pradesh. Problem-solving ability test developed by L.N. Dubey was used for this study.

Bala, Preeti, and Shaafiu,K.Q. (2016) studied on academic achievement of secondary school students in relation to their problem solving ability and examination anxiety. Descriptive survey method was used. The difference of male and female students' academic achievement, problem-solving ability and examination anxiety was also evaluated.200 secondary students of Maldives (100 males and 100 females) were randomly selected as sample. 
Examination Anxiety Scale and Problem solving ability scale were administered on 10 different secondary schools of Maldives. The study concluded that there exists no significant difference between male and female students in academic achievement, problem solving ability and examination anxiety. The study also revealed that there exists a positive correlation between academic achievement and problem solving ability and also showed that there exists a negative correlation between examination anxiety and academic achievement.

Dhadhich Anita (2016) conducted study on the problem-solving ability of $11^{\text {th }}$ standard students. The main objectives of the study were to observe the problem-solving ability of students of $11^{\text {th }}$ standard of government and private schools to observe the difference between the problem solving ability of girls and boys. For the present study, a sample of 60 students has been taken and standardized test of problem solving ability developed by Dr. Rooprekha Garg has been used. By using the various statistical techniques the result was drawn that there is significant difference between problem solving ability of boys and girls of $11^{\text {th }}$ standard students

Ahuja,J., Nagpal, P. and Kakkar, N. (2017) carried on A comparative study of problem solving ability of science and arts senior secondary school. The main objectives of the study were- to study the problem solving ability of male and female science students of senior Secondary schools, to study the problem solving ability of male and female arts students of senior Secondary schools and to study the difference if any in the problem solving ability of science and arts senior secondary school. The hypotheses made were there is no significant relationship in the problem solving ability of science and arts senior secondary schools students. Descriptive Survey Method was used for the present study. A sample of
100 students was randomly selected from the government and private schools. Problem-Solving Ability Test by L.N.Dubey was used. For the analysis of data Mean, S.D. and ' $t$ '-test was used.

Lizzie, J.(2017) carried out the study Problem Solving Ability in Mathematics in relation to their academic achievement among higher secondary students. The sample for the study consists of 300 higher secondary students selected random from government, government aided and private higher secondary students of Tiruvallur city. Descriptive Survey method was used. Descriptive analysis and inferential analysis had been utilized for this study. Null hypothesis were framed and tested. To assess the problem solving ability in mathematics, the questionnaire was constructed by the investigator. To assess the academic achievement quarterly and half yearly marks were calculated. The main finding was found a positive relationship between problem solving ability in mathematics and academic achievement.

\section{IV.CONCLUSION}

It was found that Problem-Solving Ability is significantly and positively correlated with academic achievement. Various factors like personality, study behaviour, learning style, scientific attitude, intellectual ability, exam anxiety have greater influence on Problem-Solving ability and academic achievement of school students.

\section{REFERENCES}

[1]. Ayodhya, P. (2007, Sept.). Blending ProblemSolving Skills to Learners Achievement, Edutracks, Vol.7 (No.1), Hyderabad : Neelkamal Publications, pp 34-36. 
[2]. Babitha, Ann Joseph (2015). The influence of creative problem solving ability on academic performance of secondary school students of northern Kerala. International Journal of Emerging trends in Electrical and Electronics, Vol.11,Issue-5,73-

79,sep.2015(IJETEE_ISSN:2320-9569).

Retrieved from

http://www.ijetee.org/Docs/Volume\%2011/Issu e\%205/12.p-df

[3]. Gakhar et al. (2013). Creativity, problem solving and personality in relation to scholastic achievement.Retrieved from

http://shodhganga.inflibnet.ac.in /bitstream/10603/7060/7/07-chapter\%0202.pdf

[4]. James Anice and Marice P. V. (2005, July). Select Variables as Determinants of ProblemSolving Ability. Edutracks, Vol.4 (No.11), Hyderabad : Neelkamal Publications.

[5]. Jose, N. M. and Thomas, R. P. (2011, Jan.). Problem-Solving Ability and Scholastic Achievement of Secondary School Students, GCTE : Journal of Research and Extensionin Education, Vol. 6 (1) pp 141-144.

[6]. Kishor, Vimal (2013). Academic achievement of high school students having differential levels of problem solving ability. A bi annual journal of the light of education, Vol-2,issue 01,March2013, ISSN 2277-4556.Retrieved from http://14.139.206.50:8080/jspui/bitstream/1/412 1/1/19--Academic \% 20 Achievement \% 20 of \% 20 High \% School \% 20 Students \% 20 having \% 20 Differential \% 20 Levels \% 20 of \% 20 Problem \% 20 Solving \% 20 Ability.pdf.

[7]. Mehraj, Ahmad. Bhat.,(2014) Effect of Problem Solving Abiliy on the Achievement in Mathematics of High School Students. Indian Journal of Applied Research, Vol.4, Issue 8, August 2014. Retrieved from https://www.worldwidejournals.com/indian- journal-of-applied-research-

(IJAR)/file.php?val=August_2013_1375513665_ 1c067_159.pdf

[8]. Salami, S.O. and Aremu, A. O. (2006). Relationship between problem-solving ability and study behavior among school-going adolescents in south western Nigeria. E-journal of Research in Educational Psychology, Vol. 4 (1), pp 139-154. Retrieved from http://www/investigcionpscicopedagogica.org/r evista/ articulos/8/english/Art-8-77.pdf

[9]. Schoenfeld, A. (2013). Reflections on Problem Solving Theory and Practice, Vol. 10(1\&2). Retrieved from http://www.math.umt.edu/tmme/vollo noland2/ 1-Schoenfeld/pp 9-34.pdf

[10]. Sharma, I. (2007). Problem Solving Ability and Scientific attitude as determinant of academic achievement of higher secondary students. Ejournal of All Association for Educational Research, Vol. 19 (1\&2). Retrieved from http://www.aiaer.net/ejournal/vol.19107/17.hm

\section{Cite this article as :}

Anuradha Ghatak, Prof. Kavita Mittal, "A Review Based Study on Problem-Solving Ability of School Students in Relation to their Academic Achievement", International Journal of Scientific Research in Science and Technology (IJSRST), Online ISSN: 2395-602X, Print ISSN : 2395-6011, Volume 6 Issue 2, pp. 644-649, March-April 2019. Available at doi : https://doi.org/10.32628/IJSRST1196238 Journal URL : http://ijsrst.com/IJSRST1196238 